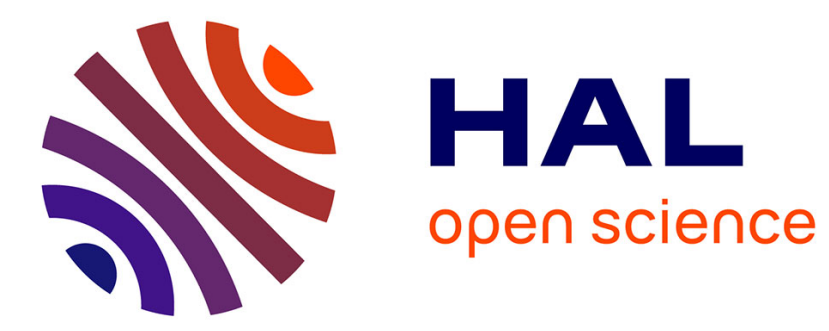

\title{
Mugilids fisheries of Tunisian coasts and lagoons
}

Mohamed Salah Romdhane, Chiheb Fassatoui, Moez Shaiek, Amel Ben Rejeb Jenhani, T. Changeux

\section{To cite this version:}

Mohamed Salah Romdhane, Chiheb Fassatoui, Moez Shaiek, Amel Ben Rejeb Jenhani, T. Changeux. Mugilids fisheries of Tunisian coasts and lagoons. Aquatic Living Resources, 2019, 32, pp.6. 10.1051/alr/2019005 . hal-02123575

\section{HAL Id: hal-02123575 https://hal.science/hal-02123575}

Submitted on 28 Jan 2020

HAL is a multi-disciplinary open access archive for the deposit and dissemination of scientific research documents, whether they are published or not. The documents may come from teaching and research institutions in France or abroad, or from public or private research centers.
L'archive ouverte pluridisciplinaire HAL, est destinée au dépôt et à la diffusion de documents scientifiques de niveau recherche, publiés ou non, émanant des établissements d'enseignement et de recherche français ou étrangers, des laboratoires publics ou privés. 


\title{
Mugilids fisheries of Tunisian coasts and lagoons
}

\author{
Mohamed Salah Romdhane ${ }^{1, *}$, Chiheb Fassatoui ${ }^{1}$, Moez Shaiek ${ }^{1}$, Amel Ben Rejeb Jenhani ${ }^{1}$ and \\ Thomas Changeux ${ }^{2}$ \\ 1 Unité de Recherche Écosystèmes et Ressources Aquatiques (UR13AGRO1), Institut National Agronomique de Tunisie, Université de \\ Carthage, 43 Avenue Charles-Nicolle, 1082 Tunis Mahrajène, Tunisie \\ ${ }^{2}$ Mediterranean Institute of Oceanography (UM 110), Aix Marseille Univ., Université de Toulon, CNRS, IRD, Campus de Luminy, \\ Océanomed, 13288 Marseille Cédex 9, France
}

Received 4 July 2018 / Accepted 15 February 2019

Handling Editor: Rutger de Wit

\begin{abstract}
With its $1300 \mathrm{~km}$ coastline and 110000 ha of coastal lagoons, Tunisia offers important resources to demersal and pelagic fisheries. Among all the exploited fish species in Tunisia, mugilids are the most widespread. They are known in temperate, subtropical and tropical regions, and occur both in coastal areas, lagoon ecosystems and inland waters. Six mugilids species have been inventoried in Tunisia. Their migratory behavior consists of moving back and forth between brackish and saline environment where they spend a large part of their life cycles. This behavior results in a peculiar high vulnerability to human pressure. Consequently, they require special attention from fisheries managers for sustainable catches. This study was based on the data from the national fishing and aquaculture directorate (DGPA) statistics, and comprised time series from 1995 to 2015 . We looked for clear tendencies and correlations between harvest from the coastal sea and lagoons of the different coastal regions, in relation to recruitment in coastal marine waters. We focused on two species, i.e. Mugil cephalus and Liza aurata, which are best appreciated for local consumption and, therefore, most targeted by the fishery in Tunisia. The Tunisian lagoons show a decreasing trend in mugilids landings. This may be explained by the disturbance of migratory ways and the degradation of the coastal habitats, by the harvest of fry used for the inland water-stocking program, and by the multiplication of droughts. Particularly the latter strongly limits the migration of juveniles. The harvest in the coastal zones is relatively stable, follows perfectly the total national landings, with although a clear increase since 2011 as a result of uncontrolled illegal fishing. The negative correlation between the total harvests of mugilids in the coastal sea and coastal lagoon was highly significant (Pearson coefficient $r=-0.702, p<0.001)$.
\end{abstract}

Keywords: Mugilids / diversity / landings / coast / lagoons Tunisia

\section{Introduction}

The Tunisian waters host about 350 marine and inland fish species, among which 6 are mugilids also known as mullets, i.e., Mugil cephalus (Linnaeus, 1758), Chelon labrosus (Risso 1827), Liza aurata (Risso 1810), Liza saliens (Risso, 1810), Liza ramada (Risso 1810) and Oedalechilus labeo (Cuvier, 1829). In practice, they are difficult to distinguish by nonspecialists, especially the juvenile forms.

In the Mediterranean Sea, mugilids represent 22.1 millions of tons in 2014 with a value of 44.2 million of US dollars ${ }^{1}$. In Tunisia, the total mugilids harvest during 2015 was almost 3000 tons which represents $9.5 \%$ of the coastal and lagoon

\footnotetext{
*Corresponding author: ramadhanms@gmail. com

' http://www. seaaroundus.org/data
}

harvest and $2.26 \%$ of the total Tunisian fisheries harvest (DGPA, 2015).

Thus, mugilids in Tunisia, beyond their great economic importance, represent an important heritage and cultural value. Indeed, since antiquity times, from Punic to Roman ages, mullets were selected among species which are part in the preparation of "Garum", an essential condiment of the ancient gastronomy in the Mediterranean basin (Paskoff et al., 1991; Slim et al., 2004). Nowadays, mullets are very much sought after and constitute a highly appreciated product, both for their organoleptic and alimentary qualities. The "Bottarga", mainly made from the roe pouch of Flathead grey mullet Mugil cephalus is collected when the females are full (Beddih et al., 2005). This product, sometime called the "Mediterranean caviar" has a high market value exceeding 200 US dollars per kilogram.

Similarly, fishing for mugilids is one of the most ancient fishery practices in Tunisia. Thus, antique representations such 


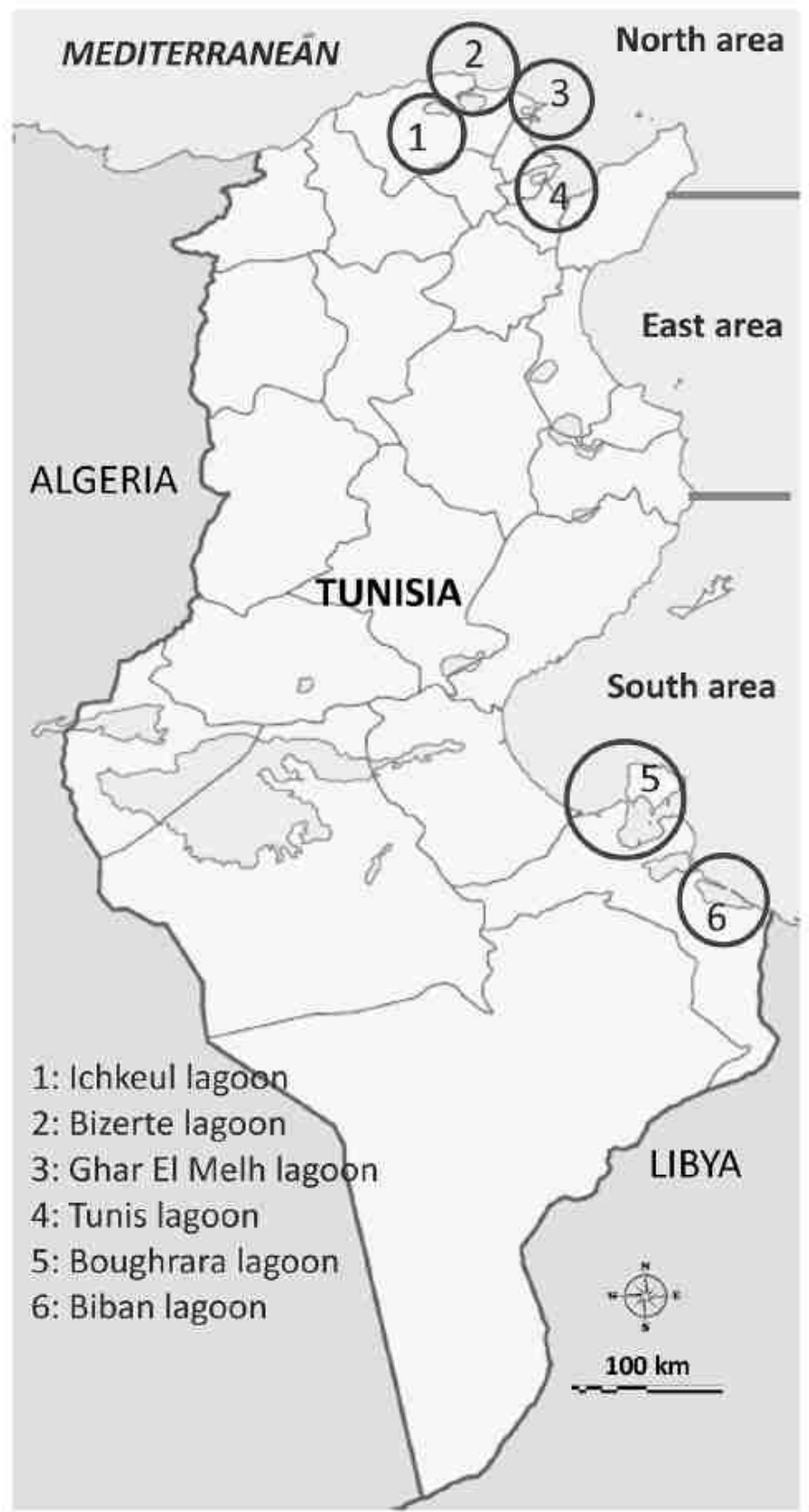

Fig. 1. Coastal areas and lagoons of Tunisia.

as the "mosaic of Sidi Abdellah" or the "Baths of Fundus Bassianus" (Bardo Museum) illustrate mugilids fishing in Bizerte lagoon by means of ancestral techniques (castnet). Ancient texts also mentioned old fishing techniques for mugilids, some of which are still practiced today like the peculiar use of female to attract other individuals (Paskoff et al., 1991; Slim et al., 2004).

The mugilids live in groups in coastal waters as well as in coastal lagoons and inland fresh waters, in lakes and dams reservoirs (Bauchot and Pras, 1980; Fischer et al., 1987; Feheri- Bedoui and Gharbi, 2005). However and because of their complicated life cycle as an euryhaline migratory species, they need good ecological status of both the coastal and lagoon habitats, on the one hand, as well as good connectivity between these different habitats, on the other hand.

The first scientific studies on the ecology, biology, growth, and fishing of mugilids in Tunisia were done by Heldt (1948), who included descriptions of stocks. Since him, studies have multiplied considering growth, reproduction, migration, nursery habitat, stocking and fishing techniques (Farrugio and Quignard, 1974; Farrugio, 1975; Bruslé and Bruslé, 1977; Chauvet and Mkaouar, 1977; Chauvet, 1979; Romdhane, 1985; Vidy and Franc, 1987; Fehri-Bedoui and Gharbi, 2005).

This study mainly focused on two species, i.e., the Flathead Grey Mullet Mugil cephalus (Linnaeus, 1758) and the golden mullet Liza aurata (Risso, 1810). Indeed, both species represent together the essential of mugilids landings in Tunisia (DGPA, 2015). According to Fehri-Bedoui and Gharbi (2005), Liza aurata represents alone $45 \%$ of the total national landings of mugilids. The aim was to find clear tendencies and correlations between coastal and lagoon landings, either between spawning, growth in inland (rivers, natural and artificial lakes), littoral ecosystems (lagoons) and recruitment in coastal marine waters.

This review on the diversity and exploitation of mugilids in Tunisia includes three main axes: the spatial distribution of species through lagoons and coastal areas; the specific fishing gears and the analysis of the landings status and trends.

\section{Tunisian coastal areas and lagoons}

The spatial distribution of mugilids is constrained by local and geographical conditions. We distinguish three marine coastal areas (North, East and South), five coastal lagoons (Bizerte, Ghar El Melh, Tunis, Boughrara, Biban) and a single inland lagoon (Ichkeul) where mugilids are fished (Fig. 1).

The Tunisian coasts extend over $1298 \mathrm{~km}$ and represent a hinge zone between the two Mediterranean basins. Based on biogeographic and bioclimatic criteria, the fishing zones of Tunisia are subdivided into three main coastal areas (see Tab. 1 and Fig. 1): the Northern area (extended Gulf of Tunis), the Eastern area (Gulf of Hammamet and Sahel region) and the Southern zone (Gulf of Gabes).

The coastal lagoons are shallow inland water bodies, separated from the ocean by a barrier, connected to the ocean by one or more restricted inlets which remain open at least intermittently (Kjerfve, 1994). According to the geomorphological, hydrological and climatic aspects, 10 lagoons are identified in Tunisia (Quignard and Zaouali, 1980), here we focus on six lagoons that are most important for fisheries (Tab. 2):

- lagoon of Ichkeul, the only inland lagoon, which is connected to the Bizerte lagoon and the receptacle of six semi-permanent rivers;

- Bizerte lagoon with a $300-\mathrm{m}$ wide marine channel as the inlet;

- Ghar El Melh with a 20 to 50 -m wide inlet;

- Tunis lagoons (north and south) communicate throw hydraulic tidal gates;

- Boughrara the largest lagoon of Tunisia with a 3000-m wide inlet:

- Biban lagoon communicates with a 400 -m wide inlet. 
Table 1. Major characteristics of marine coastal area of Tunisia (Ktari-Chakroun and Azouz, 1971; Ben Othman, 1973; Oueslati, 1993).

\begin{tabular}{llll}
\hline Fishery Zones & Spatial delimitation & Common substrates & Common Fishing zones \\
\hline Northern coast & Gulf of Tunis & Rocky bottoms and movable bottoms & $\begin{array}{l}\text { Tabarka, Sidi Mechreg, Bizerte, } \\
\text { Ghar El Melh, Goulette } \\
\text { Eastern coast }\end{array}$ \\
& Gulf of Hammarnet & Sandy bottoms & $\begin{array}{l}\text { Kelibia, Beni Khiar, Hergla, Sousse, } \\
\text { Monastir, Teboulba, Mahdia }\end{array}$ \\
Southern coast & Gulf of Gabes & Sandy and sandy-muddy bottoms & $\begin{array}{l}\text { Sfax, Kerkennah, Mahres, Skhira, Gabes, } \\
\text { Zarat, Houmt Souk, Zarzis, Ketf }\end{array}$ \\
\hline
\end{tabular}

Table 2. Major characteristics of the Tunisian lagoons.

\begin{tabular}{|c|c|c|c|c|c|c|}
\hline Lagoons & Surface & Mean depth & Temperature ranges & Salinity ranges & Water exchange & References \\
\hline $\begin{array}{l}\text { Ichkeul } \\
\left(37^{\circ} 81^{\prime} \mathrm{N} 9^{\circ} 83^{\prime} \mathrm{E}\right)\end{array}$ & $\begin{array}{l}8000 \text { to } 12000 \text { ha } \\
\text { (summer to } \\
\text { winter phase) }\end{array}$ & 1 to $2 \mathrm{~m}$ & 10 to $33^{\circ} \mathrm{C}$ & 0.20 to $80 \mathrm{psu}$ & Bizerte lagoon & $\begin{array}{l}\text { Ben Hassine, 1974; } \\
\text { Ben Rejeb Jenhani, 1989; } \\
\text { Beji Sassi, 1999; Ben M' } \\
\text { barek, 2001; ANPE, } 2007\end{array}$ \\
\hline $\begin{array}{l}\text { Bizerte } \\
\left(37^{\circ} 10^{\prime} \mathrm{N} 09^{\circ} 50 \mathrm{\prime}\right)\end{array}$ & $15000 \mathrm{ha}$ & 8 to $12 \mathrm{~m}$ & 11 to $29^{\circ} \mathrm{C}$ & 33.9 to $35.8 \mathrm{psu}$ & Mediterranean sea & $\begin{array}{l}\text { Harzallah, 2002; } \\
\text { Béjaoui et al., 2010; } \\
\text { Boukef et al., 2010; } \\
\text { MeHSIP-PPIF, 2011 }\end{array}$ \\
\hline $\begin{array}{l}\text { Ghar El Melh } \\
\text { lagoon } \\
\left(37^{\circ} 08^{\prime} \mathrm{N} 10^{\circ} 10^{\prime} \mathrm{E}\right)\end{array}$ & $2600 \mathrm{ha}$ & 0.5 to $1 \mathrm{~m}$ & 9.7 to $27.4^{\circ} \mathrm{C}$ & 25.0 to $46.0 \mathrm{psu}$ & Gulf of Tunis & $\begin{array}{l}\text { Romdhane, 1985: } \\
\text { Burgis and Symoens, 1987; } \\
\text { Lemoalle, } 1987\end{array}$ \\
\hline Tunis Lake & & & & & & \\
\hline $\begin{array}{l}\text { North part: } \\
\left(36^{\circ} 49^{\prime} \mathrm{N} 10^{\circ} 14^{\prime} \mathrm{E}\right)\end{array}$ & $2200 \mathrm{ha}$ & 1 to $3 \mathrm{~m}$ & 10 to $29^{\circ} \mathrm{C}$ & 34 to $42.5 \mathrm{psu}$ & Gulf of Tunis & $\begin{array}{l}\text { Ben Charrada, } \\
\text { 1992; Ben Maiz, }\end{array}$ \\
\hline $\begin{array}{l}\text { South part: } \\
\left(36^{\circ} 47^{\prime} \mathrm{N} 10^{\circ} 13^{\prime} \mathrm{E}\right)\end{array}$ & 710 ha & 2 to $4 \mathrm{~m}$ & 10 to $32^{\circ} \mathrm{C}$ & 37.2 to $37.4 \mathrm{psu}$ & & 2008; Jouini et al., 2005 \\
\hline $\begin{array}{l}\text { Boughrara } \\
\left(33^{\circ} 36^{\prime} \mathrm{N} 10^{\circ} 49^{\prime} \mathrm{E}\right)\end{array}$ & $50000 \mathrm{ha}$ & $4 \mathrm{~m}$ & 11.2 to $27.4^{\circ} \mathrm{C}$ & 36.9 to 44.4 psu & Gulf of Gabes & $\begin{array}{l}\text { Jedoui et al., 1981; } \\
\text { Romdhane et al., 1998; } \\
\text { Ben Aoun et al., 2007; } \\
\text { Kharroubi et al., 2012 }\end{array}$ \\
\hline 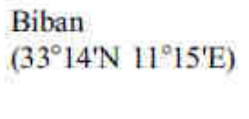 & 30000 ha & $4 \mathrm{~m}$ & 6 to $30^{\circ} \mathrm{C}$ & $40.0-50.0 \mathrm{psu}$ & Gulf of Gabes & $\begin{array}{l}\text { Medhioub, 1979; } \\
\text { Lemoalle and Vidy, 1984; } \\
\text { Jouili et al., } 2017\end{array}$ \\
\hline
\end{tabular}

Lagoon biodiversity is relatively important where different faunistic and floristic groups are represented, with a distribution largely conditioned by the specificity of each lagoon (Tab, 3).

\section{Mullet fishing gears and techniques}

Despite a homogeneous distribution of the six mugilids species over all sites (Tab. 4), the harvests remain dependent on fishing gears and efforts. According to the recent fishing gear guide of Tunisia, (Romdhane et al., 2014), mullets are caught multi-specifically (with other fishes, meaning the fishing is non-selective) by various types of gillnets, trammel nets and combined nets. Mugilidae are caught by two types of traps, namely the weir (in lagoons), and the fixed traps (artisanal Charfia).

The veranda net is another gear targeting specifically mullet (Farrugio, 1975; Romdhane, 1998; Romdhane et al., 2014). This gear is used mainly on the coast (concentrated in the eastern and southern regions of Tunisia).

Finally, a bait fishing technique, quite unique and dating from antiquity (Slim et al., 2004), is used up to now and it targets specially mullets. The traditional fishing by females' attraction is practiced mainly in the northern Tunisia (Romdhane, 1998). We have noted that mullets can be caught incidentally by other types of fishing encircling nets purse seine or "Lamparo" (light fishing). Major fishing gears targeting mullets are listed in Table 5 . 
Table 3. Tunisian Lagoon biodiversity.

\begin{tabular}{|c|c|c|c|c|c|c|c|}
\hline Lagoons & $\begin{array}{l}\text { Phytoplankton } \\
\text { (N species) }\end{array}$ & $\begin{array}{l}\text { Macrophytes } \\
\text { (N species) }\end{array}$ & $\begin{array}{l}\text { Zooplankton } \\
\text { (N species) }\end{array}$ & $\begin{array}{l}\text { Invertebrates } \\
\text { ( } \mathrm{N} \text { species) }\end{array}$ & $\begin{array}{l}\text { Fishes } \\
\text { (N species) }\end{array}$ & $\begin{array}{l}\text { Hydrological } \\
\text { specificities }\end{array}$ & References \\
\hline Ichkeul & 32 & 21 & 12 & 20 & 22 & $\begin{array}{l}\text { 2nd degree lagoon with } \\
\text { continental water } \\
\text { tributaries and } \\
\text { communicating with } \\
\text { Bizerte lagoon }\end{array}$ & $\begin{array}{l}\text { Ben Rejeb Jenhani et al., } \\
\text { 1991; Chaouachi and } \\
\text { Ben Hassine, 1998; Romdhane, } \\
\text { 2002; Kraïem et al., 2003; } \\
\text { Shaiek et al., } 2016\end{array}$ \\
\hline Bizerte & 56 & 86 & 21 & 150 & 45 & $\begin{array}{l}\text { Large and deep lagoon } \\
\text { with deep channel as the } \\
\text { inlet }\end{array}$ & $\begin{array}{l}\text { Azouz, 1966; Zaouali, 1980; } \\
\text { Beji, 2000; Sakka et al., } \\
2003\end{array}$ \\
\hline $\begin{array}{l}\text { Ghar } \\
\text { El Melh }\end{array}$ & 74 & 13 & 41 & 84 & 49 & $\begin{array}{l}\text { Shallow lagoon with } \\
\text { restricted lagoon-sea } \\
\text { exchanges }\end{array}$ & $\begin{array}{l}\text { Romdhane, 1985; Romdhane } \\
\text { and Ktari, 1986; Shili et al., } \\
\text { 2002; Kraiem et al., } 2009 \text {. }\end{array}$ \\
\hline Tunis & 56 & 38 & 43 & 85 & 15 & $\begin{array}{l}\text { Medium surface and depth } \\
\text { lagoon with tide-regulated } \\
\text { water } \\
\text { exchange (gates) }\end{array}$ & Ben Maiz, 2008; Turki, 2004 \\
\hline Boughrara & 84 & 15 & 48 & 100 & 31 & $\begin{array}{l}\text { Large and deep lagoon } \\
\text { with large lagoon-sea } \\
\text { exchanges } \\
\text { in the West and limited } \\
\text { exchanges in the East }\end{array}$ & $\begin{array}{l}\text { Zaouali, 1980; Daly Yahia } \\
\text { and Romdhane, 1994; } \\
\text { Ben Rejeb Jenhani and } \\
\text { Romdhane, 2002; Shili and } \\
\text { Ben Maiz, 2003 }\end{array}$ \\
\hline Biban & 47 & 35 & 19 & 80 & 42 & $\begin{array}{l}\text { Large and deep lagoon } \\
\text { with considerable lagoon- } \\
\text { sea exchanges }\end{array}$ & $\begin{array}{l}\text { Zaouali, 1982; Lemoalle and } \\
\text { Vidy, } 1984\end{array}$ \\
\hline
\end{tabular}

Table 4. Mugilids distribution in Tunisians waters.

\begin{tabular}{|c|c|c|c|c|c|c|c|c|}
\hline Zones/Species & $\begin{array}{l}\text { Mugil } \\
\text { cepahlus }\end{array}$ & $\begin{array}{l}\text { Liza } \\
\text { ramada }\end{array}$ & $\begin{array}{l}\text { Chelon } \\
\text { labrosus }\end{array}$ & $\begin{array}{l}\text { Liza } \\
\text { saliens }\end{array}$ & $\begin{array}{l}\text { Liza } \\
\text { aurata }\end{array}$ & $\begin{array}{l}\text { Oedalechilus } \\
\text { labeo }\end{array}$ & $\begin{array}{l}\text { Major } \\
\text { disturbance }\end{array}$ & Authors \\
\hline \multicolumn{9}{|l|}{ Lagoons } \\
\hline Ichkeul & $\mathrm{x}^{* *}$ & $\mathrm{X}^{* *}$ & & $\mathrm{x}$ & $\mathrm{x}$ & & $\begin{array}{l}\text { Drought and } \\
\text { limited recruitment }\end{array}$ & $\begin{array}{l}\text { Ben Hassine, 1974; Farrugio, } \\
\text { 1975; Bruslé and Bruslé, } \\
\text { 1977; Vidy and Franc, 1989; } \\
\text { Fehri-Bedoui and Gharbi, 2005; } \\
\text { ANPE 2007, DGPA, 2015 }\end{array}$ \\
\hline Bizerte* & $\mathrm{X}$ & $\mathrm{X}^{* *}$ & $\mathrm{x}$ & & $\mathrm{X}$ & & Water pollution & $\begin{array}{l}\text { Heldt, 1948; Farrugio, 1975; } \\
\text { MeHSIP-PPIF, 2011; } \\
\text { DGPA, 2015 }\end{array}$ \\
\hline Ghar El Melh ${ }^{*}$ & $\mathrm{x}^{*}$ & $\mathrm{X}$ & & $\mathrm{X}$ & $\mathrm{X}^{* *}$ & & $\begin{array}{l}\text { Recruitment } \\
\text { disturbance }\end{array}$ & $\begin{array}{l}\text { Heldt, 1948; Farrugio, 1975; } \\
\text { Romdhane, 1985; Vidy and } \\
\text { Franc, 1989; DGPA, } 2015\end{array}$ \\
\hline Tunis ${ }^{*}$ & $\mathrm{x}^{*}$ & $\mathrm{X}^{*}$ & $\mathrm{x}$ & $\mathrm{x}$ & $\mathrm{X}$ & & $\begin{array}{l}\text { Tidal regulated } \\
\text { recruitment, } \\
\text { IUU fishing }\end{array}$ & $\begin{array}{l}\text { Heldt, 1948; Farrugio and } \\
\text { Quignard, 1974; Farngio, 1975; } \\
\text { Vidy and Franc, 1989; } \\
\text { Ben Maiz, 2008; DGPA, } 2015\end{array}$ \\
\hline Hergla & $\mathrm{X}$ & $\mathrm{X}$ & $\mathrm{X}$ & $\mathrm{X}$ & $\mathrm{X}$ & & $\begin{array}{l}\text { Recruitment } \\
\text { disturbance } \\
\text { shallow water }\end{array}$ & Blel et al,, 2008; DGPA, 2015 \\
\hline Boughrara ${ }^{*}$ & $\mathrm{X}$ & $\mathrm{x}$ & & $\mathrm{X}$ & $\mathrm{X}$ & & Pollution & $\begin{array}{l}\text { Farrugio, 1975; Vidy and Franc, } \\
\text { 1989; Guetat et al., 2012; } \\
\text { DGPA, } 2015\end{array}$ \\
\hline Biban $^{*}$ & $\mathrm{X}$ & $\mathrm{X}$ & $\mathrm{x}^{* *}$ & $\mathrm{X}^{* *}$ & $\mathrm{X}$ & & IUU fishing & $\begin{array}{l}\text { Heldt, 1948; Farrugio, 1975; } \\
\text { Vidy and Franc, 1989; } \\
\text { Blel et al., 2008; DGPA, } 2015\end{array}$ \\
\hline
\end{tabular}


Table 4. (continued),

\begin{tabular}{|c|c|c|c|c|c|c|c|c|}
\hline Zones/Species & $\begin{array}{l}\text { Mugil } \\
\text { cepahlus }\end{array}$ & $\begin{array}{l}\text { Liza } \\
\text { ramada }\end{array}$ & $\begin{array}{l}\text { Chelon } \\
\text { labrosus }\end{array}$ & $\begin{array}{l}\text { Liza } \\
\text { saliens }\end{array}$ & $\begin{array}{l}\text { Liza } \\
\text { aurata }\end{array}$ & $\begin{array}{l}\text { Oedalechilus } \\
\text { labeo }\end{array}$ & $\begin{array}{l}\text { Major } \\
\text { disturbance }\end{array}$ & Authors \\
\hline \multicolumn{9}{|c|}{$\begin{array}{l}\text { Costal zones } \\
\text { (marine ecosystems) }\end{array}$} \\
\hline Northern zone & $\mathrm{X}$ & $\mathrm{X}$ & $\mathrm{X}$ & $\mathrm{X}$ & $\mathrm{X}$ & $\mathrm{X}$ & Fry collecting & Quignard and Raibaut, 1971; \\
\hline Eastern zone & $\mathrm{x}$ & $\mathrm{x}$ & $\mathrm{x}$ & $\mathrm{X}^{* *}$ & $\mathrm{X}$ & $\mathrm{x}$ & Fry collecting & Tortonese, 1972 \\
\hline Southern zone & $\mathrm{X}$ & $\mathrm{X}$ & $x^{* *}$ & $\mathrm{x}$ & $\mathrm{X}$ & $x$ & $\begin{array}{l}\text { Fry collecting } \\
\text { and Pollution }\end{array}$ & $\begin{array}{l}\text { Ben Hassine, 1974; } \\
\text { Farrugio and Quignard, 1974; } \\
\text { Farrugio, 1975; } \\
\text { Vidy and Franc, 1993; } \\
\text { Blel et al., 2008; } \\
\text { Bradai, 2000; DGPA, } 2015\end{array}$ \\
\hline
\end{tabular}

Lagoons and zones were specific mullets fishing activities are performed

" dominants species

Note: All authors have confirmed up to now the absence of Oedalechilus labeo in lagoon ecasystems. It is an exclusively marine species.

Table 5. Fishing gears used in Tunisian lagoons and coastal areas.

\begin{tabular}{|c|c|c|c|c|c|c|c|c|c|c|}
\hline Gears & Lines & Long lines & Cast net & $\begin{array}{l}\text { Trammel } \\
\text { net/gillnet }\end{array}$ & $\begin{array}{l}\text { Fyke } \\
\text { net }\end{array}$ & $\begin{array}{l}\text { Encircling } \\
\text { net }\end{array}$ & Trawl & $\begin{array}{l}\text { Veranda } \\
\text { net }\end{array}$ & $\begin{array}{l}\text { Weirs } \\
\text { Charfia }\end{array}$ & Bordigue (trap net) \\
\hline Ichkeul & & & & $\mathrm{x}$ & $\mathrm{x}$ & & & & & In use \\
\hline Bizerte ${ }^{*}$ & $x$ & $\mathrm{x}$ & & $x$ & & & & & & $\begin{array}{l}\text { Left on } 1948 \text { in operation } \\
\text { until } 1948 \text { then abandoned }\end{array}$ \\
\hline Ghar El Melh ${ }^{*}$ & & $\mathrm{x}$ & $x$ & $\mathrm{x}$ & $\mathrm{x}$ & & & & & Left on 1973 \\
\hline Tunis lake ${ }^{*}$ & $\mathrm{x}$ & & $\mathrm{x}$ & $\mathrm{x}$ & $\mathrm{x}$ & & & & & $\begin{array}{l}\text { Reinstalled in } 2005 \text { (north lake) } \\
\text { Left on } 1995 \text { (south lake) }\end{array}$ \\
\hline Korba & & & $\mathrm{x}$ & & & & & & & Project in 1897 \\
\hline Hergla & & & $\mathrm{x}$ & & $\mathrm{x}$ & & & & & Project in 1897 \\
\hline Khniss & & & $x$ & $\mathrm{x}$ & & & & & & Left on 1990 \\
\hline Boughrara $^{*}$ & & $\mathrm{x}$ & $\mathrm{x}$ & $\mathrm{x}$ & & & & & & \\
\hline Biban & $\mathrm{x}$ & $\mathrm{x}$ & & $\mathrm{x}$ & & & & & & In use \\
\hline Northern zone & & & $\mathrm{x}$ & $x$ & & $\mathrm{x}$ & $\mathrm{x}$ & & & \\
\hline Eastern zone & & & $\mathrm{x}$ & $\mathrm{x}$ & & $\mathrm{x}$ & $\mathrm{x}$ & $\mathrm{x}$ & & \\
\hline Southern zone & & & $\mathrm{x}$ & $\mathrm{x}$ & & $\mathrm{x}$ & $\mathrm{x}$ & $\mathrm{x}$ & $\mathrm{x}$ & \\
\hline
\end{tabular}

- Lagoons were mugilids fishing activities are performed

\section{Mullets landings in Tunisia}

Statistics of mullet harvest catches or landings were collected from national fisheries and aquaculture directorate (DGPA, Direction Générale de la Pêche et de l'Aquaculture) of the Ministry of Agriculture, Water Resources and Fisheries of Tunisian Republic. These statistics come from the databases that constitute the Tunisian system for collecting fishing data from the regional port directorates along the Tunisian coasts. The data were structured to obtain total landings per year, by fishing origin (coastal and lagoon), by region (Northern, Eastern and Southern of Tunisia) and by main mullet categories. Descriptive analyzes were performed to underscore a potential correlation between landings and stocks of several mullet fishing origin (total, coastal and lagoon landings). A complete time series of statistical data was obtained for the period 1995 to 2015 .

\subsection{Total landings of mullets in Tunisia}

The average total mullet landings per year is around 2184 $(\mathrm{SD}=413.44)$ tons over the studied period. A long and relatively stagnancy period of the annual landed fish quantity is observed from 1995 to 2011 , when an increasing landing occurs and maintained up to 2015 (Fig. 2). When we compare the current period of investigation (1995/2015) to earlier observation periods in the twentieth century, i.e., 1923-1937 and 1969-1971 reported by Farrugio (1975), we notice respectively a significant increase in terms of quantities 597 , 1311 and 2184 tons, but a significant decrease in terms of percentage of the total fisheries captures: $8.6,4.85$ and $2.03 \%$. On the basis of monthly average landings of mullets, for the period 1995-2015, the highest seasonal catches were recorded from September to January with a maximum of 450 tons in October (Fig. 3). 


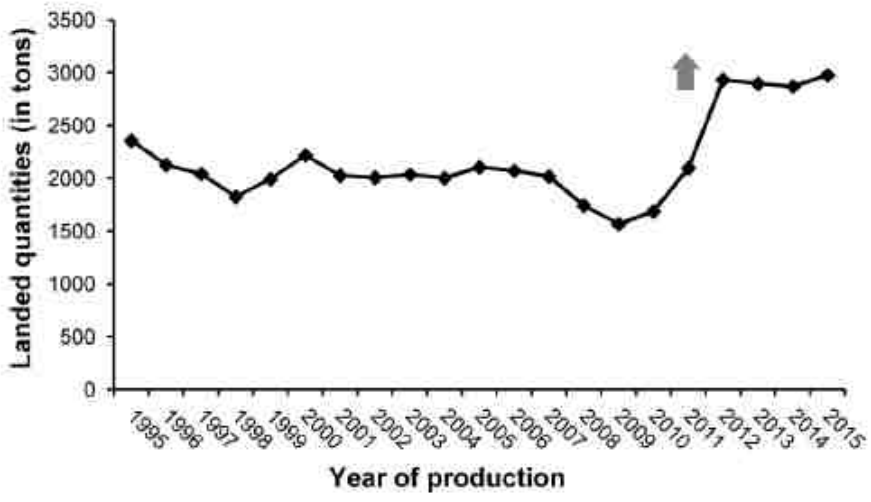

Fig. 2. Total national landing quantities of mullets per year in Tunisia between 1995 and 2015 (graph built according to the statistics of the national fishing and aquaculture direction of the Ministry of Agriculture, Water Resources and Fisheries of Tunisian Republic).

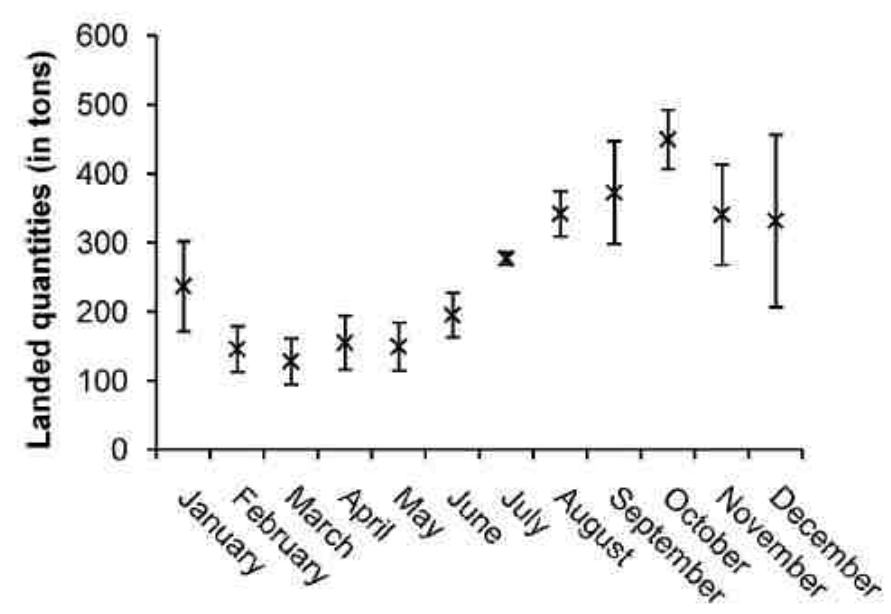

Fig. 3. Variation of the monthly mean mullet landings in Tunisia and its standard deviation for the period 1995-2015.

\subsubsection{Coastal landings of mullets in Tunisia}

The total frame landings follows closely the profile of marine coastal landings with an average over years of about $2173 \pm 410$ tons. The general tendency of the global national landings of the mugilids shows the same decline trends as marine coastal landings (Fig. 4A). A slight stability is observed during the period 1995-2010.The decline of the mullet landings is the most significant for the first time in 1998 ( 1697.27 tons). Then, the general landings evolution tends to decrease, year after year to the lowest level in 2009 (1568 tons). Since 2011, a rapid and significant increase occurs and remains relatively stable until 2015 .

\subsubsection{Lagoon landings of mullets in Tunisia}

At first glance, the lagoon mullet landings appear unchanged from year to year, and show a low correlation with coastal landings, as well as the total national landings of mullets. When we refined the scale to have a better view of the lagoon landings in front of the important quantities of the
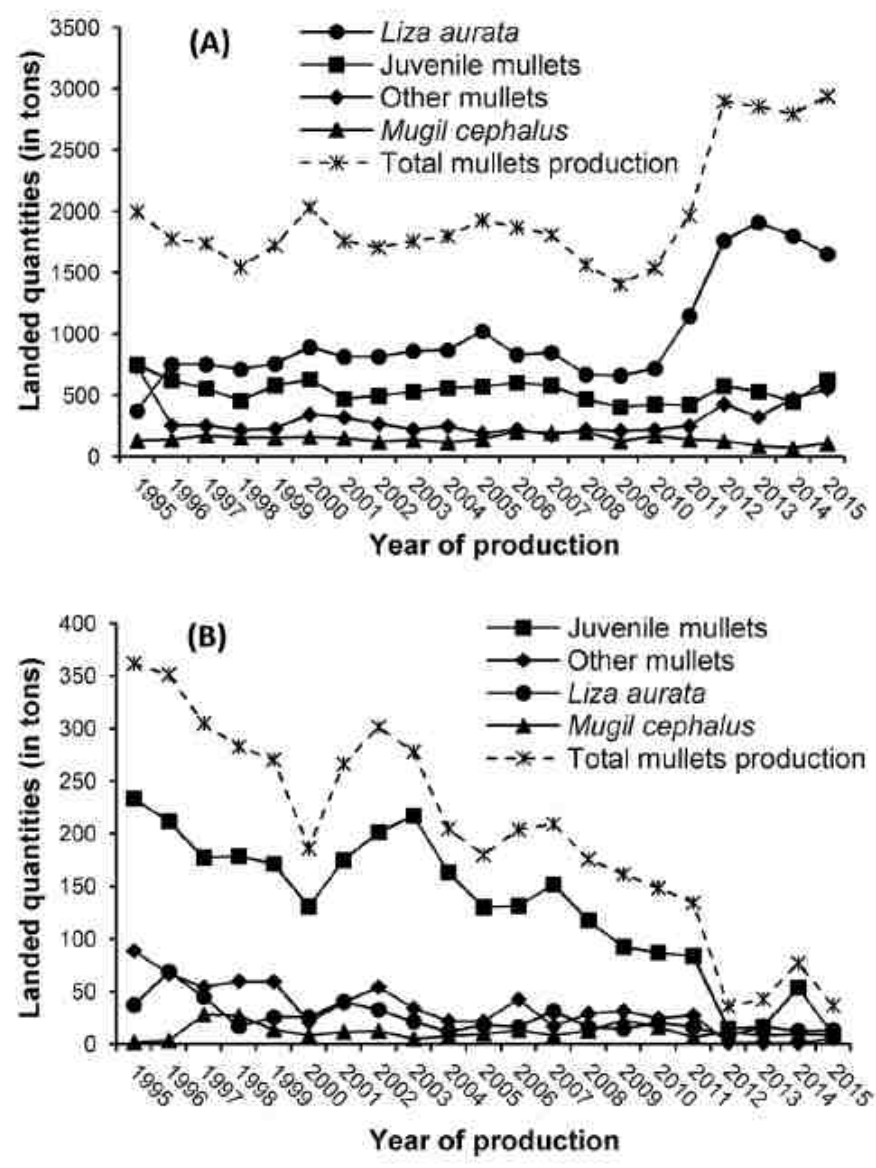

Fig. 4. Evolution of coastal landings (A) and lagoon landings (B) of the total and the major species of mullets (Liza aurata, juvenile mullets, other mullets, Mugil cephalus) during period from 1995 to 2015 in Tunisia (graph was built according to the statistics of the national fishing and aquaculture direction of the Ministry of Agriculture, Water Resources and Fisheries of Tunisian Republic).

costal landings (Fig. 4B), the average lagoon mullet landings per year is around $200 \pm 99$ tons.

The yearly productivity of lagoons varies from 0.5 to $6.5 \mathrm{~kg} . \mathrm{ha}^{-1}$, where juvenile catches are dominant. Moreover, lagoons with the highest marine exchanges (Bizerte, Tunis, Boughrara and Biban) show the lowest yields (Tab. 6).

Landings from lagoons show an important inter-annual variation with a downward trend perceptible during the last decade, and especially in 2012 when catch statistics showed a net drop falling to about 36.32 tons (Fig. 4B).

One explanation of this decline could be inherent to a juvenile recruitment deficit linked to natural disturbance of sea-lagoons exchanges related to swell nourishment or erosion of the inlet, and maybe also be related to the removal of mullets fry required for inland water reservoirs stocking. Thus, according to Touzeau and Gouzé (1995), there is not necessarily a straight forward "stock-recruitment mathematical function", which does not mean that there is no relationship between these two entities. In addition, the decline of river inputs (due to hydraulic derivation, drought consecutive to 
Table 6. Mean yearly harvest (in $\mathrm{kg} / \mathrm{yr} / \mathrm{ha}$ ) of mugilids during the period 1995-2011.

\begin{tabular}{lllllll}
\hline & Ichkeul & Bizerte & Ghar El Melh & Tunis & Biban & Boughrara \\
\hline Other mugilids & 2.6 & 0.2 & 1.4 & 0.6 & 0.1 & 0.2 \\
Juvenile mugilids & 3.3 & 0.5 & 4.9 & 1.7 & 0.3 & 1.9 \\
Mugil cephalus & 0.5 & 0.0 & 0.3 & 0.0 & 0.1 & 0.0 \\
Liza aurata & 0.0 & 0.1 & 0.1 & 0.1 & 0.0 & 0.4 \\
Total & 6.5 & 0.8 & 6.7 & 2.5 & 0.5 & 2.5 \\
\hline
\end{tabular}
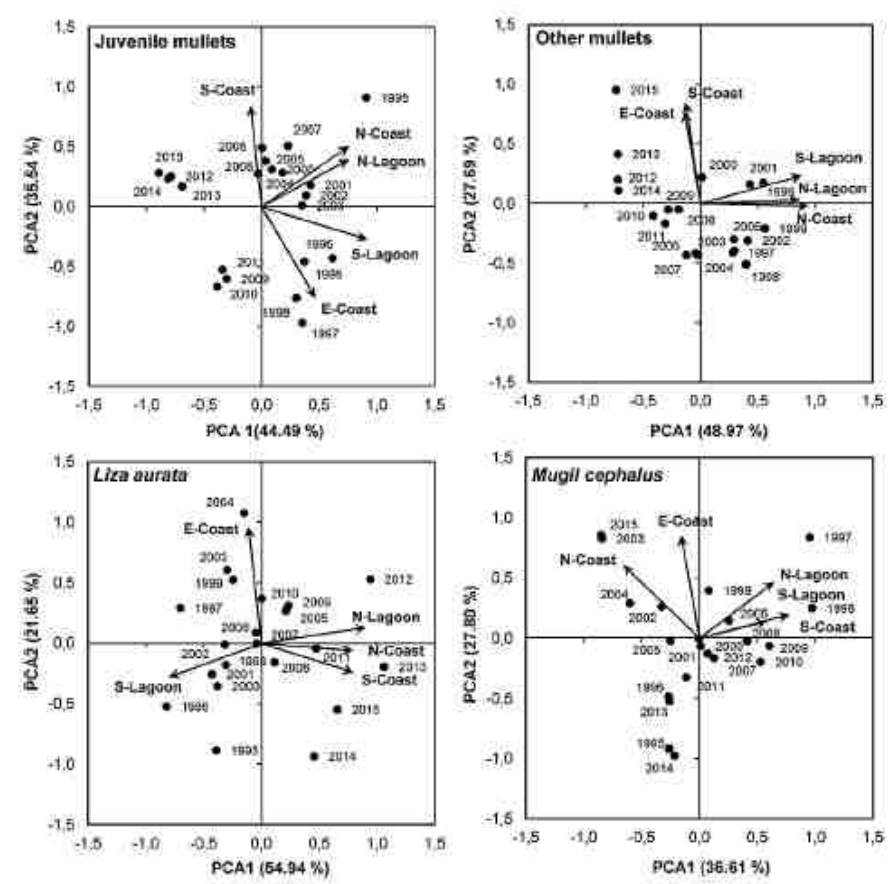

Fig. 5. Principal component analyses based on annual landings of mullets between 1995 and 2015 for the two major species and two other categories (undetermined juveniles, adults of other mullet species) separately and according to fishing origin (coastal and lagoon) and region in Tunisia ( $\mathrm{N}$ : Northern region, E: Eastern region and S: Southern region).

global warming, etc) may be an additional explanation as these rivers contribute supply of nutrients and stimulate the productivity of the various trophic levels, both in lagoons and in coastal areas (Salen-Picard et al., 2002; Darnaude et al., 2004).

The comparison of the lagoon mullet harvest with the coastal mullet harvest over years shows a relative controversial evolution. Indeed, coastal harvest of mullets seems to be negatively correlated with lagoon harvests. The most important increasing harvest peaks of lagoon mullet harvest correspond to declining ones in the coastal harvest (Fig. 4B) especially discemible from 2011 , a politically vulnerable period, when illegal fishing has grown in coastal areas.

\subsection{Landings of the major mullets species in Tunisia}

As said in introduction, there is a high probability of confusion for species identification in mullet landings. The computation and/or logging data for fishing administration is not always performed by specialists. To overcome such problems when assessing mullet landings, two miscellaneous categories were created including "juvenile of mullets" and "other mullets" (other than Liza aurata and Mugil cephalus), respectively. The assessments of the total coastal and total lagoon landings of the major species of mullets during the period from 1995 to 2015 in Tunisia are shown in Figure 4A and $\mathrm{B}$. The most important coastal landings is recorded for the golden grey mullet (Liza aurata), followed respectively by "juvenile mullets", "other mullets" species, and finally the flathead grey mullet (Mugil cephalus). The landings of the major species of mullets are almost the same and stable over years. Only, the coastal-landed quantity of Liza aurata presents a high landings value since 2011 with a peak in 2013 of 1910.50 tons. However, the total lagoon landings, despite its very low value compared to coastal landings, shows that "juvenile mullets" are the most caught, followed by "other mullets", then Liza aurata and Mugil cephalus. Variation of lagoon landings over years is observed mainly for "juvenile mullets" and "other mullets" with an overall decreasing trend. In contrast, the landed quantities of Liza aurata and Mugil cephalus from lagoon are relatively stable over the years studied.

To better characterize the landings of mullets by major species in Tunisia, we carried out a principal component analysis (ACP) taking into account the year of landings of each species separately according to the main administrative coastal and lagoons regions (northern, eastern and southern landings in Tunisia).

According to the ACP results, it appears that Mugil cephalus is more abundant in landings of the southern coasts and northern and southern lagoons of Tunisia. However, Liza aurata is more present in the northern coasts and southern lagoons landings. Eastern coastal landings of mullets contribute weakly in the total national landings. The total annual landings of "juvenile mullets" and "other mullets" are mainly supported by the southern coastal regions (Fig. 5). The landings of "juvenile mullets" in southern and northern lagoons have a similar tendency.

The national coastal landings of Mugil cephalus and Liza aurata have almost the same trend as "other mullets" and "juvenile mullets" landings. These landings are mainly supplied by coastal landings of southern region, clearly far ahead to the northern and eastern landings. These two regions contribute secondarily to the national landings.

For lagoon landings, in the case of Mugil cephalus and Liza aurata, national landings are supplied by southern and northern lagoons, on close proportions. This similarity between Southern and Northern landings is more important for Liza aurata than for Mugil cephalus. Thus, unshipped 
quantities of mullets in the southern region contribute to the supply of the national landings more clearly for the coastal landings than for lagoon landings.

Another important point to note from ACP results is that the landings of 2014 for Mugil cephalus and "juveniles mullets" show a remarkably low catches. This might be due to uncontrolled fishing or even to natural disturbance. Indeed, the environments they inhabit are strongly affected by anthropogenic and climate changes. The estuaries they need to cross are more and more often dried out during their migration phase. Furthermore, when water resource is enough, dams are constructed and form impassable barriers.

\section{Conclusion}

The mullet exploitation in Tunisian lagoon and coastal areas focuses on five species among the six Tunisian mullet species, while the statistics only describe three species in detail together with one multi-specific juvenile group. The irregular landings of mullets in lagoons are commonly linked with the recruitment; but the increasing of the coastal landings of juvenile can be interpreted as a consequence of overfishing. Regarding the high commercial and culinary value of mugilids in Tunisia, these species currently representing about $2.03 \%$ of total fisheries catch, are targeted by a considerable fishing effort. Catch data analysis reveals a specific disparity where quantitatively Mugil cephalus predominates in the South and Liza ramada in the North. Moreover, mullet exploitation seems to reach overexploitation as confirmed by continuous regression of the proportion of mullets in total fish catches, but also by the increase of small mullets (Bigeron) catches. The lagoon yield has fallen sharply during recent decades, probably in relation to the fry fishery intended for stocking inland reservoirs. Hence, control of recruitment and mullet breeding appear to be essential and vital for the sustainability of the mullet fisheries in Tunisia.

\section{References}

ANPE. Rapport sur le suivi scientifique au Parc National de l'Tehkeul, Année 2006-2007, Ministère de l'Environnement et du Développement durable, République tunisienne, 2007, pp. 1-86.

Azouz. A. 1966. Étude des peuplements et des possibilités d'ostréiculture du lac de Bizerte. Ann Inst Nat Scient Tec Oceanogr Pêche Salammbó 15: 1-69.

Azouz A. Étude des biocénoses benthiques et de la faune ichtyologique des fonds chalutables de la Tunisie. Région nord et sud-est, Thèse de doctorat en Sciences Naturelles de l'Université de Caen, 1971, AO 6471, pp. 1-255.

Bauchot ML, Pras A. Guide des poissons marins d'Europe, Delachaux \& Niestlé, Neuchâtel (Switzerland), 1980, 427 p.

Beddih MLOA, El Cafsi M, Marzouk B, Zarrouk K, Romdhane MS. 2005. Compositions chimiques et énergétiques des boutargues du Mullet Mugil cephalus et de la Courbine Argyrosomus regius en Mauritanie. Bull Inst Natn Scien Tech Mer de Salammbô 32: 31-37,

Béjaoui B, Ferjani D, Zaaboub N, Chapelle A, Moussa M. 2010. Caractérisation hydrobiologique saisonnière de la lagune de Bizerte (Tunisie). J Water Sci 23: 215-232.

Beji O.2000. Les ressources vivantes exploitables du lac de Bizerte: état actuel et potentialités. Bull Inst Natn Scien Tech Mer de Salammbó 27: 45-60.
Beji Sassi A. Les lagunes côtières de Tunisie, Complementary thesis, University of Tunis, Tunisia, 1999.

Ben Aoun Z, Farhat F, Chouba L, Hadj-Ali MS. 2007. Investigation on possible chemical pollution of the Boughrara lagoon, south of Tunisia, by chemical wastes. Bull Inst Natn Scien Tech Mer de Salammbô 34: 119-127.

Ben Charrada R. 1992. Le Lac de Tunis après les aménagements. Paramètres physico-chimiques en relation avec la croissance des microalgues. Marine Life 1: 29.44.

Ben Hassine $\mathrm{OK}$. Contribution à l'étude des copépodes parasites des muges de Tunisie, Thèse de doctorat, Faculté des sciences de Tunis, Tunisie, 1974.

Ben M'barek N. Étude de l'écosystème du lac Ichkeul et de son bassin versant : caractéristiques physiques et géochimiques des eaux et des sédiments, Thèse de Doctorat, Université de Tunis II, Tunisie, 2001.

Ben Maiz N. The natural environment of north lake Tunis. Lake Tunis and fort Chikly From water springs lifes and civilisation unfold, SPLT, Tunisia, 2008, pp. 96-119.

Ben Othman S. Le Sud tunisien (Golfe de Gabès): hydrologie, sédimentologie, flore et faune, Thèse de doctorat en Biologie Marine, Faculté des Sciences de Tunis, Tunisie, 1973.

Ben Rejeb Jenhani A. Le lac Ichkeul: conditions de milieu, peuplements et biomasses phytoplanctoniques, Thèse de doctorat, Université do Tunis, Tunisie, 1989.

Ben Rejeb Jenhani A, Romdhane MS. 2002. Impact des perturbations anthropiques sur l'évolution du phytoplancton de la lagune de Bougrara, (Tunisie). Bull Inst Natn Scien Tech Mer de Salammbô 29: $65-75$,

Ben Rejeb Jenhani A, Kartas F, Lemoalle J, Amblard C, 1991. Phytoplancton du lac Ichkeul (Tunisie) : composition, structure et activité photosynthétique. Int Rev Hydrobiol 76: 241-256.

Blel H, Chatti N, Besbes R, Said K. 2008. Phylogenetic relationships in grey mullets (Mugilidae) in a Tunisian lagoon. Aquac Res 39: 268-275.

Boukef I, Mejri S, Mraouni R, Bejaoui B, Belhassan M, Harzallah A, Boudabous A, Monia Elbour M. 2010. Distribution spatiale des populations de Vibrionaceae thermotolérants dans une lagune côtière (lagune de Bizerte : Nord-Tunisie). Spatial distribution of thermotolerant Vibrionaceae populations in a coastal lagoon (Bizerta lagoon: Northern Tunisia). Mar Life 17: 13-23.

Bradai MN. Diversité du peuplement ichtyque et contribution à la connaissance des sparidés, Thèse de Doctorat d'État en sciences naturelles, Université de Sfax, Faculté des Sciences de Sfax, 2000, $600 \mathrm{p}$.

Bruslé J, Brusłé S. 1977. Les muges de Tunisie : pêche lagunaire et biologie de la reproduction de trois espèces (Mugil capito, Mugil cephalus et Mugil chelo) des lacs d'Ichkeul et de Tunis. Rapp Comm Int Mer Médit 24: 101-130.

Burgis MJ, Symoens JJ. 1987. Zones humides et lacs peu profonds d'Afrique. Éditions de I'Institut Français de Recherche Scientifique pour le Développement en Coopération. Collections Travaux et Documents, ORSTOM 211: $34-61$.

Chaouachi B, Ben Hassine OK. 1998. The status of fish biodiversity in Ichkeul Lagoon, Tunisia. Ital J Zool 65: 303-304.

Chauvet C. 1979. Estimations du peuplement de muges du lac et de la baie de Tunis. Rapp Comm Int Explor Mer Médit 25/26-3:141-142.

Chauvet C, Mkaouar M. 1977. Résultats d'une expérience de marquage sur les muges de lac de Tunis. Bull Off Natl Pêch Tunisie 1: $181-187$.

Daly Yahia MN, Romdhane MS. 1994. Dynamique trophique du Zooplancton et relation Phytoplancton-Zooplancton au sein de l'écosystème de la mer de Bou Grara. Bull Inst Natn Scien Tech Mer de Salammbó 21: 47-65. 
Darnaude A, Salen-Picard C, Polunin NC, Harmelin-Vivien M. 2004. Trophodynamic linkage between river runoff and coastal fishery yield elucidated by stable isotope data in the Gulf of Lions (NW Mediterranean). Oecologia 138: 325 -332.

DGPA. Annuaire des statistiques de pêche en Tunisie. Direction Générale de la Pêche et de l'Aquaculture (DGPA), Ministère de l'Agriculture, des Ressources Hydrauliques et de la Pêche, République tunisienne, $2015,137 \mathrm{p}$.

Farrugio H. Les muges (poissons, téléostéens) de Tunisie. Répartition et pêche, Contribution à leur étude systématique et biologique, Thèse de Doctorat en Sciences Naturelles, Académie de Montpellier, Université des Sciences et Techniques du Languedoc, France, 1975.

Farrugio H, Quignard JP. 1974. Biologie de Mugil (Liza) ramada (Risso, 1826) et Mugil (Chelon) labrosus (Risso, 1826) (Poissons, Téléostéens, Mugilidés) du lac de Tunis. Bull Inst OcéanogrPêche Salammbo 2: 565-578.

Fehri-Bedoui R, Gharbi H. 2005. Âge et croissance de Liza aurata (Mugilidae) des côtes tunisiennes. Cybium 29: 119-126.

Fischer W, Schneider M, Bauchot ML. Fiches FAO d'Identification des Espèces pour les Besoins de la Pêche. Méditerranée et Mer Noire. Zone de Pêche 37, Révision 1. Vol. II, Vertébrés, FAO, Rome, 1987, pp. 763-1529.

Guetat F, Sellam F, Akrout F, Brahim M, Atoui A, Ben Romdhane MS, Daly Yahia MN. 2012. État environnemental de la lagune de Boughrara et ses alentours deux ans après les travaux d'aménagement et d'élargissement du pont d'El Kantara. Bull Inst Natn Scien Tech Mer de Salammbo 39: 149-160.

Harzallah A. État actuel et évolution de l'exploitation halieutique et aquacole des lagunes-Cas de la lagune de Bizerte, Rapport, Institut National des Sciences et Technologies de la Mer, Salammbô, Tunisie, 2002, 128 p.

Heldt JH. 1948. Contribution à l'étude de la biologie des muges des lacs tunisiens. Bull Stat Océanogr Salammbô 41: $2-35$.

Jedoui Y, Bobier CL, Cirac P, Pujos M. 1981. Contribution à la connaissance des systèmes lagunaires en domaine méditerranéen. Hydrologie et Sédimentologie du Bahiret el Bou Grara (Tunisie). Tethys 10: 39-52.

Jouili S, Essid N, Semprucci F, Boufahja F, Nasri A, Beyrem H, Mahmoudi E. 2017. Environmental quality assessment of El Bibane lagoon (Tunisia) using taxonomic and functional diversity of meiofauna and nematodes, J Mar Biol Assoc U.K. 97 (8): $1593-1603$.

Jouini Z, Ben Charrada R, Moussa M. 2005. Caractéristiques du Lac Sud de Tunis apres sa restauration Characteristics of the South Lake of Tunis after restoration. Mar Life 15(1-2): 3-11.

Kharroubi A, Gzam M, Jedoui Y. 2012. Anthropogenic and natural effects on the water and sediments qualities of costal lagoons: Case of the Boughrara Lagoon (Southeast Tunisia). Environ Earth Sci 67: 1061-1067.

Kjerfve B. Coastal lagoons, in: B. Kjerfve (Ed.), Coastal lagoon processes, Elsevier Science Publishers, Amsterdam, 1994, pp. 1-8.

Kraiem MM, Ramdani M, Fathi AA, Abdelzaher HMA, Flower RJ. 2003. Analyse de la biodiversité et de la production ichtyque dans trois lacs nord africains: Merja Zerga (Maroc), Garaat Ichkeul (Tunisie) et Lac Edku (Egypte). Bull Inst Natn Scien Tech Mer de Salammbó 30: 5-13.

Kraiem MN, Chouba L, Ramdani M, Ahmed MH, Thomson JR, Flower RJ. 2009. The fish fauna of three North African lagoons: Specific inventories, ecological status and production. Hydrobiologia 622: 133-146.
Ktari-Chakroun F, Azouz A. 1971. Les fonds chalutables de la région sud-est de la Tunisie (Golfe de Gabès). Bull Inst Natn Scient Tech Océanogr Pêche Salammbố 2: 5-47.

Lemoalle J. Lagunes côtières de Tunisie, Chap 1.2, in: Zones humides et lacs peu profonds d'Afrique, Collections Travaux et Documents ORSTOM, 1987, Vol. 211, pp. 34-61.

Lemoalle J, Vidy G. Conditions du milieu et pêche dans la lagune hyper saline d'El Biban (Tunisie), Étude et travaux FAO, 1984, Vol. 1, 61, pp. 175-195.

Medhioub K. 1979. La "Bahiret el Biban". Ettude géochimique et sédimentologie d'une lagune du Sud-Est Tunisien. Travaux du Laboratoire de Géologie, Presse de l'École Normale Supérieure, Paris, Vol. $13,150 \mathrm{p}$.

MeHSIP-PPIF. Dépollution Intégrale Lac de Bizerte Mediterranean. Hot Spot Investment Program Project Preparation and Implementation Facility Rapport Diagnostic, 2011, 186 p.

Oueslati A. Les Côtes de la Tunisie: géomorphologie et environnement et aptitudes à l'aménagement, Publications de l'Université de Tunis, Tunisie, 1993, 387 p.

Paskoff R, Slim H, Trousset P. Le littoral de la Tunisie dans l'Antiquité: cinq ans de recherches géo-archéologiques, in: Comptes rendus des séances de l'Académie des Inscriptions et Belles-Lettres, $135^{\circ}$ année, 1991, VoL. 3, pp. 515-546.

Quignard JP, Raibaut A. 1971. Présence de Mugil (Oedalechilus labeo) Cuvier, 1829 dans les eaux tunisiennes. Bull Inst Océanogr Pêche, Salambô 2(2): 163-168.

Quignard JP, Zaouali J. 1980. Les lagunes périméditerranéennes. Bibliographie ichthyologique annotée. Bull Off Nat Pêches Tunisie 4: 293-360.

Romdhane MS. Lagune de Ghar E1 Melh: milieu, peuplement, exploitation, Thèse de doctorat, Université de Tunis, Tunisie, 1985.

Romdhane MS. 1998. La pêche artisanale en Tunisie. Évolution des techniques ancestrales. Mélanges de l'Ecole française de Rome, Antiquité, tome 110 , no 1, pp. 61-80.

Romdhane MS. État des réserves de la Biosphère de la Tunisie, la réserve de la Biosphère de l'Ichkeul, Commission Nationale du MAB Tunisie, 2002, 44 p.

Romdhane MS, Ktari C. 1986. Les peuplements benthiques de la lagune de Ghar El Melh. Bull Inst Natn Tech Océanogr Pêche Salammbô 13: 95-108.

Romdhane MS, Mrabet R, Rais C, Dhouib S, Kheriji A. Engins de pêche de Tunisie. Projet pour une pêche durable en Tunisie. WWF, INAT, INSTM et Fondation OAK, 2014, 64 p.

Romdhane MS, Yahia OKD, Jenhani AB, Yahia MD. 1998. Ressources piscicoles et proliférations phytoplanctoniques dans les lagunes tunisiennes (Cas de Boughrara et Ghar El Melih). Centenaire de IIINAT, 511-526.

Sakka Hlaili A, Chikhaoui MA, El Grami B, Hadj Mabrouk H, 2003. Variation hiverno-estivale de la communauté phytoplanctonique de la lagune de Bizerte en milieux naturel et fertilisé en nutriments. Rev Fac Sci Bizerte Tunisia 2: 37-49.

Salen-Picard C, Darnaude AM, Arlhac D, Harmelin-Vivien ML. 2002. Fluctuations of macrobenthic populations: A link between climate-driven river runoff and sole fishery yields in the Gulf of Lions. Oecologia 133: 380-388.

Shaiek M. Fassatoui C, Romdhane MS. 2016. Past and present fish species recorded in the estuarine Lake Ichkeul, northern Tunisia. Afr. J Aqua Sci 41: 171-180.

Shili A, Ben Maiz N. Diversité spécifique des peuplements phytobenthiques de la lagune de Boughrara (Tunisie méridionale), Proceedings of the second Mediterranean symposium on marine vegetation, Athens, 12-13 December 2003. RAC/SPA Publication, Tunis, 2003, pp. 242-243. 
Shili A, Trabelsi EB, Ben Maiz N. 2002. Benthic macrophyte communities in the Ghar El Melh lagoon (Northem Tunisia). $J$ Coast Conserv 8: 135-140.

Slim H, Trousset P, Paskoff R. Le littoral de la Tunisie. Étude géoarchéologique et historique, Éditions du Centre National de la Recherche Scientifique (études d'antiquités africaines), Paris, 2004 , pp. $3-308$.

Tortonese E. 1972. I Mugilidi del bacino mediterraneo. Natura Soc It Sc Nat 63(1): 21-36.

Touzeau S, Gouzé JL. A propos des relations stock-recrutement. Modélisation et représentation des connaissances, Deuxième Forum Halieumétrique, Nantes, 1995, pp. 225-229.

Turki S. 2004. Suivi des microalgues planctoniques toxiques dans les zones de production, d'élevage des mollusques bivalves et d'exploitation des oursins du nord de la Tunisie. Bull Inst Natn Scien Tech Mer de Salammbó 31: 83-96.
Vidy G, Franc J. Ressource naturelle en alevins de Mugilidés en Tunisie, Rapport scientifique pour le Ministère de l'Agriculture (CGP-INSTOP), ORSTOM, Tunisie, 1987, 213 p.

Vidy G, Franc J. 1989. Contribution à la connaissance de Oedalechilus labeo (Cuvier, 1829) (poissons, mugilidés): alevins de Tunisie. Bull Soc Zoo Fr 114(4), 67-79.

Vidy G, Franc J. 1993. Saisons de présence à la côte des alevins de muges (Mugilidae) en Tunisie. Cybium 16(1): 53-71.

Zaouali J. 1980. Flore et faune benthiques de deux lagune tunisiennes: lac de Bizerte (Tunisie septentrionale) et mer de Boughrara (Tunisie méridionale). Bull Off Nat Pêche Tunisie 4: 169-200.

Zaouali J. 1982. Bionomie benthique de la mer des Bibans: zone centrale et bassin oriental. Actes Symp. Internat. Sur les lagunes côtières, SCOR/IABO/UNESCO, Bordeaux, sept. 1981. Oceanologica Acta numéro spécial: 457-461.

Cite this article as: Romdhane MS, Fassatoui C, Shaiek M, Ben Rejeb Jenhani A, Changeux T. 2019. Mugilids fisheries of Tunisian coasts and lagoons. Aquat. Living Resour: 32: 6 